The University of Maine

DigitalCommons@UMaine

Marine Sciences Faculty Scholarship

School of Marine Sciences

$2-1-2002$

\title{
Redescription of Hyalella Azteca from Its Type Locality, Vera Cruz, Mexico (Amphipoda : Hyalellidae)
}

E. R. Gonzalez

Les Watling

University of Maine - Main, watling@maine.edu

Follow this and additional works at: https://digitalcommons.library.umaine.edu/sms_facpub

\section{Repository Citation}

Gonzalez, E. R. and Watling, Les, "Redescription of Hyalella Azteca from Its Type Locality, Vera Cruz, Mexico (Amphipoda : Hyalellidae)" (2002). Marine Sciences Faculty Scholarship. 101.

https://digitalcommons.library.umaine.edu/sms_facpub/101 


\title{
REDESCRIPTION OF HYALELLA AZTECA FROM ITS TYPE LOCALITY, VERA CRUZ, MEXICO (AMPHIPODA: HYALELLIDAE)
}

\author{
Exequiel R. Gonzalez and Les Watling
}

\begin{abstract}
Darling Marine Center, University of Maine, 193 Clark's Cove Rd., Walpole, Maine 04573, U.S.A. (ERG present address): Facultad de Ciencias del Mar, Universidad Católica del Norte, Casilla 117, Coquimbo, Chile (e-mail: egonzale@nevados.ucn.cl); (LW e-mail: watling@maine.edu)
\end{abstract}

\section{A B S T R A C T}

\begin{abstract}
Hyalella azteca is a species complex distributed in North, Central, and northern South America. The identity of the species has always been a problem, especially because the original description by Saussure (1858) from a "cistern" in Vera Cruz, Mexico, is poor, and the figures are not clear. Since then, mention of the type material or specimens from the type locality has not been made by investigators using the name $H$. azteca. Ecological and genetic information available today suggests that there are several species in the complex commonly referred to as $H$. azteca. The subtle morphological differences among the populations have made the problem of defining these species very complicated. To aid in this process, we present here the morphological description of $H$. azteca based on the syntype series established by Saussure and deposited in the Muséum d'Histoire Naturelle, Ville de Genève, Switzerland.
\end{abstract}

Hyalella Smith, 1874, is known only from the Nearctic and Neotropical biogeographical regions. Forty-four species have been described. One of the species, Hyalella azteca (Saussure, 1858), is considered to be a common freshwater organism found all over North America, Central America, and northern South America. The original description by Saussure (1858), based on samples from a "cistern" in Vera Cruz and Ciudad de Mexico, Mexico, is poorly described and figured. In North and Central America, most of the freshwater species of Hyalella recorded are assigned to Hyalella azteca; however, seven other related species are known from the region: $H$. texana Stevenson and Peden, 1973, from Clear Creek Spring, Texas; $H$. montezuma Cole and Watkins, 1977, from Montezuma Well, Arizona; $H$. squamosa Mateus and Mateus, 1990, from Guadeloupe, West Indies; $H$. caribbeana Bousfield, 1996, from Riviere Bell Eau, Grande Terre Guadeloupe, West Indies; $H$. longicornis Bousfield, 1996, from St. George's Golf course, Kenilworth?, Utah; $H$. muerta Baldinger, Shepard, and Threloff, 2000, from California, U.S.A. (hypogean); and $H$. sandra Baldinger, Shepard, and Threloff, 2000, from California, U.S.A.

The first putative species of Hyalella from North America was described as early as 1818 by Say from marshes in South Carolina as Ampithoe dentata. Stebbing (1906) synonymized this species under Hyalella azteca.
Later, Bousfield (1958) attributed Ampithoe dentata to Crangonyx serratus (Embody, 1910). Bate (1862) defined Allorchestes knickerbockeri from material deposited in the British Museum, collected by Say in North America and labeled as Gammarus minus. Smith (1874) described the new genus Hyalella based on Allorchestes knickerbockeri Bate, 1862, Amphithoe azteca Saussure, 1858, and his own material from the United States. He also described a new species, $H$. dentata, collected from several places in the United States from Oregon to Maine. This species is considered to be different from $H$. knickerbockeri (Bate, 1862). One year later Smith (1875) redescribed the genus Hyalella and $H$. dentata and added a new species from Colorado, U.S.A., H. inermis Smith, 1875. Harford (1877) described Lockingtonia fluvialis from Lobos Creek, California, U.S.A., and most likely was unaware of the work of Smith $(1874,1875)$. For many years the name Hyalella was not used after it was synonymized under Allorchestes by Faxon (1876). Stebbing (1903) described Hyalella faxoni from Costa Rica and reestablished the genus name. Stebbing (1906) synonymized $H$. knickerbockeri (Bate, 1862), $H$. dentata, $H$. inermis, and Lockingtonia fluvialis under $H$. azteca, but did not mention $H$. faxoni. Weckel (1907) put $H$. faxoni in the synonymy of $H$. knickerbockeri, which she thought had precedence over $H$. dentata Smith, 1874. She 
did not see the work of Stebbing (1906) who had already put $H$. knickerbockeri under $H$. azteca. She also did not mention Saussure's species, indicating that she considered it a valid separate species in the sense of Smith (1874, 1875). The Michigan-Walker expedition in 1910 collected material from Lake Catemaco Vera Cruz, Mexico, close to the type locality of $\mathrm{H}$. azteca (Saussure, 1858). Although Pearse (1911) analyzed the material, either he did not consider or was unaware of Saussure`s work and described Hyalella ornata, which was later synonymized under $H$. azteca by Shoemaker (1933).

The lack of obvious morphological variation and detailed study of $H$. azteca resulted in all the authors believing that the species was present all over North and South America. Multiple references to $H$. azteca are mentioned in the literature, resulting in a widespread species, ranging from Alaska to Tierra del Fuego and from California to Newfoundland (Shoemaker, 1933; Ruffo, 1947). A list of the different locations would be too long to mention here, but for details see Weckel (1907, 1910), Pearse (1913, 1914, 1921), Shoemaker (1933, 1935, 1942, 1948), Barnard and Barnard (1983), and Bousfield (1996). Some recent literature of $H$. azteca outside North America includes Brazil (Pereira, 1983), Bermuda (Lazo-Wasem and Gable, 1989), Chile (González, 1991), and Venezuela (Villarroel and Graziani, 1995).

Hyalella azteca has been the subject of numerous studies in ecology, life history, biology, and especially toxicology. Without exception and regardless of the geographical location in North America, these studies refer to the species as $H$. azteca. Although there was always some doubt about the identity of the species involved, no one attempted to solve the problem. Strong (1972) studied populations from eight different places in Oregon and found significant differences in the life histories among the three population groups he analyzed. The biogeographical variation, size-specific fecundity, size-biased predation by fishes, reproductive isolation, and several studies on reproductive strategies of $H$. azteca (France, 1992; Wellborn, 1994a, b, 1995, 2000; McPeek and Wellborn, 1998) indicate consistent variation among the populations studied.

Several recent genetic studies using allozymes (Duan et al., 1997, 2000; Hogg et al., 1998) and allozymes and PCR (Thomas et al., 1994, 1997, 1998; Witt and Hebert, 2000) on populations of $H$. azteca from a wide geographical area in North America indicate low levels of gene flow, reduction in genetic variability, low heterozygosity, unique alleles, and strong genetic differentiation and divergence among the populations.

From these ecological and genetic studies it is clear that $H$. azteca is a species complex. None of the above studies, however, mention any morphological differences among the populations included in the analysis.

We present here a detailed morphological description of Hyalella azteca based on the syntype series used by Saussure in 1858 when he originally described the species. The material was deposited in the Muséum d'Histoire Naturelle, Ville de Genève, Switzerland.

The numerous records currently synonymized under this species complex and the incomplete descriptions and figures have prompted us to avoid any attempt to give a complete synonymy for $H$. azteca until the morphology of other populations in North and Central America have been thoroughly studied. We did, however, have the opportunity to examine the type series of $H$. ornata Pearse, 1911 , and it is included here as a synonym of $H$. azteca.

\section{MATERIALS AND METHODS}

Measurements of the specimens were made from the tip of the head to the base of the telson. This convention was chosen because of the variable position of the tip of the telson in different specimens. The computer program Image-Pro Plus (Media Cybernetics, 1997) was used to measure the specimens. The description was generated using the taxonomic database DELTA (Dallwitz et al., 1999). The terminology for setae follows Watling (1989) and Oshel and Steele (1988)

Here we designate, from the syntype series, the figured material as the Lectotype (male, $7.8 \mathrm{~mm}$ ) for the species. The material is deposited in the Muséum d'Histoire Naturelle, Ville de Genève, Switzerland. The Lectotype lot consists of a vial with the body and eleven permanent slides with the appendages. The rest of the syntype series now become part of the paralectotype series.

The following abbreviations are used in the figures: A, antenna; E, epimeral plates; G, gnathopod; U, upper lip; L, lower lip; M, mandible; P, peraeopod; S, maxilliped; $\mathrm{T}$, telson; X, maxilla; R, uropod. Lower-case letters on the left side of capital letters refer to specimens cited in captions. Lower case letters on the right are as follows: 1 , left; $r$, right. The scale is indicated as a small bar on each appendage, "a" is equivalent to 206 microns; " $b$ " is equivalent to 100 microns; "c" is equivalent to $50 \mathrm{mi}$ crons; " $\mathrm{d}$ " is equivalent to 660 microns. 
TAXONOMIC DESCRIPTION

Hyalella azteca (Saussure, 1858)

Figs. 1-5

Amphitoe aztecus Saussure, 1858: 474, 475, fig. 33, 33a-e.

Hyalella ornata Pearse, 1911: 109, 110, fig. 2.

Diagnosis.-Pleonite 1 and 2 with dorsoposterior carina. Maxilla 1, inner plate with 3 strong and pappose apical setae. Gnathopod 1 , propodus hammer shaped, palm slope transverse, no setae on anterior border, inner face with 4 pappose setae, setose scales on distoposterior and distoanterior border. Gnathopod 2 , basis hind margin with 2 setae; propodus palm shorter than posterior margin, slope slightly oblique, irregular, anterior edge with wide truncated process. Uropod 3, ramus as long as peduncle, styliform, with 4 simple and 1 connate apical setae. Telson as wide as long, rounded, but apically pointed, with 2 apposed long simple apical setae.

Description of Male.-Size, $7.8 \mathrm{~mm}$. Pleonite 1 and 2 with dorsoposterior carina. Epimeral plate 1 round, 2 and 3 slightly acuminate (Fig. 1E). Coxae 1 to 4 subequal in size and shape, slightly overlapping. Coxa 4 deeper than wide, excavated posteriorly. Coxa 5 anterior and posterior lobes subequal. Coxa 6 anterior lobe very small.

Head smaller than first two thoracic segments, typically gammaridean, rostrum absent. Eyes pigmented, black, medium, round, located between insertion of antenna 1 and 2 (Fig. 1H).

Antenna 1 less than half body length, shorter than antenna 2 , slightly longer than peduncle of antenna 2; flagellum 7 articles, longer than peduncle, basal article not elongated; peduncle longer than head, article 1 longer and wider than 2 and 3 , article 3 same as 2; asthetascs on flagellum (not shown in figure) from article 3 distally (Fig. 1, A1).

Antenna 2 less than half body length; peduncle slender, longer than head, article 4 same length as article 5; flagellum of 8 articles, much longer than article 5 , basal article elongated (Fig. 1, A2).

Basic amphipod mandible (in the sense of Watling, 1993); incisor toothed; left lacinia mobilis with 5 teeth; seta row on left mandible with 3 setae, right mandible with 2 setae; molar large, cylindrical, and triturative, accessory seta present (Fig. 1, Mr and Ml).
Labrum ventral margin round (Fig. 1, U). Lower lip outer lobes rounded, without notches or excavations, mandibular projection of outer lobes round (Fig. 1, L).

Maxilla 1 palp uniarticulate, longer than wide, reaching half length of distance between base of palp and tip of setae on outer plate; inner plate slender, smaller than outer plate, with 3 strong and pappose apical setae; outer plate with 9 stout and serrate setae (Fig. 2, X1r and X11).

Maxilla 2 inner plate slightly shorter and slender than outer plate, 2 strong pappose setae on inner margin (Fig. 1, X2).

Maxilliped inner plates flat, apically truncated, with 3 connate setae, pappose setae apically and medially; outer plates larger than inner plates, flat, apically truncated, apical, medial, and facial setae simple; palp longer than outer plate, 4 articles; article 2 wider than long, medial border with long simple setae; article 3 outer distal margin with long plumose setae, distal margin with long simple setae, inner medial margin with long simple setae; terminal article unguiform, with long simple setae, inner border with setae, distal nail present (Fig. 2, S).

Gnathopod 1 subchelate, smaller than gnathopod 2; carpus longer than wide, longer than and as wide as propodus, with strong and wide posterior lobe, produced, forming scoop-like structure open to the inside, inner face with 1 to 3 pappose setae, pectinate border and several long pappose setae; propodus rectangular, hammer shaped, with no setae on anterior border, inner face with 4 pappose setae, setose scales on distoposterior and distoanterior border; palm slope transverse, posterior distal corner with robust setae and cup for dactylus; dactylus claw-like, congruent with palm (Fig. 1, G1).

Gnathopod 2 subchelate; basis hind margin with 2 setae; merus with 7 or more setae on posterior margin, posterodistal margin concave, distal corner pointed acute, distal and posterior margin with scales; carpus posterior lobe elongated, produced between merus and propodus, border pectinate, with several pappose setae; propodus rectangular, setose scales on distoposterior border, palm shorter than posterior margin, slope slightly oblique, irregular, with few strong short setae, several long setae, and few medium-size setae, anterior edge with wide truncated process, posterior distal corner with strong setae and cup 

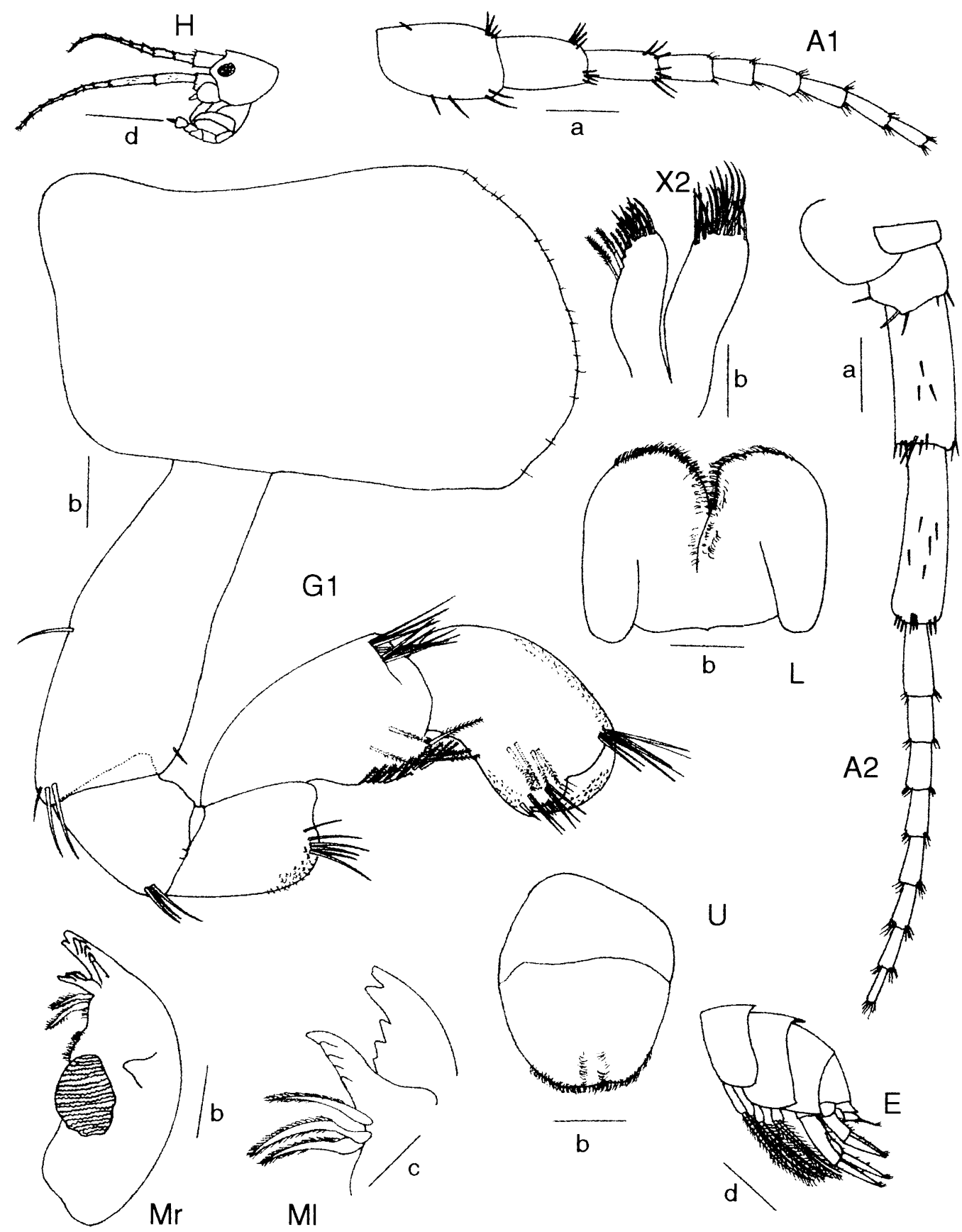

Fig. 1. Hyalella azteca male, length $7.8 \mathrm{~mm}$. Symbols for figures are as follow: A, antenna; E, epimeron; G, gnathopod; U, upper lip; L, lower lip; M, mandible; P, peraeopod; S, maxilliped; T, telson; X, maxilla; R, uropod. Lower case letters on the right are as follow: l, left; r, right. The scale is indicated as a small bar on each appendage, "a" is equivalent to 206 microns; " $b$ " is equivalent to 100 microns; "c" is equivalent to 50 microns; "d" is equivalent to 660 microns.

for dactyl; dactylus claw-like, congruent with palm, with several endal setae (Fig. 2, G2).

Peraeopods 3 to 7 simple. Peraeopods 3 and 4 merus and carpus posterior margin with 4 hind marginal clusters of short setae; propo- dus posterior margin 2 to 4 groups of setae; dactylus less than half length of propodus (Fig. 3, P3 and P4). Peraeopods 5 to 7 all similar in structure and slightly longer successively. Peraeopod 5 subequal to peraeopod 4, 


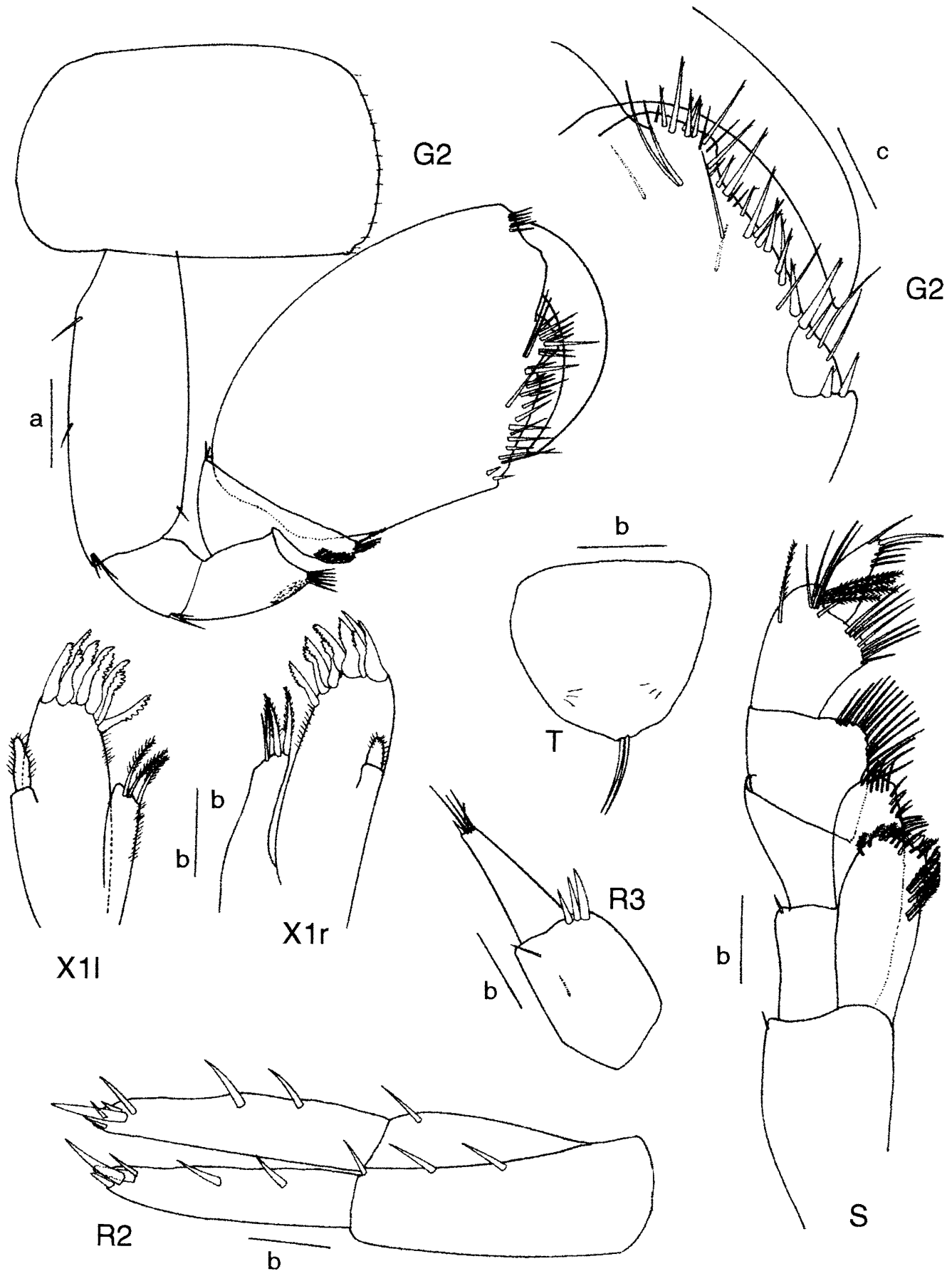

Fig. 2. Hyalella azteca male, length $7.8 \mathrm{~mm}$. Symbols and scale as in Fig. 1 .

basis posterior lobe wider than deep, smaller than posterior lobe of peraeopod 7 , merus with 2 hind marginal setae (Fig. 3, P5). Peraeopod 6 longer than peraeopod 4 , basis posterior lobe deeper than wide, smaller than posterior lobe of peraeopod 5 , and smaller than posterior lobe of peraeopod 7 (Fig. 5, P6). Peraeopod 7 subequal to peraeopod 6, basis posterior lobe wider than deep (Fig. 4, P7).

Pleopods not modified; peduncle slender. Uropod 1 longer than uropod 2; peduncle 


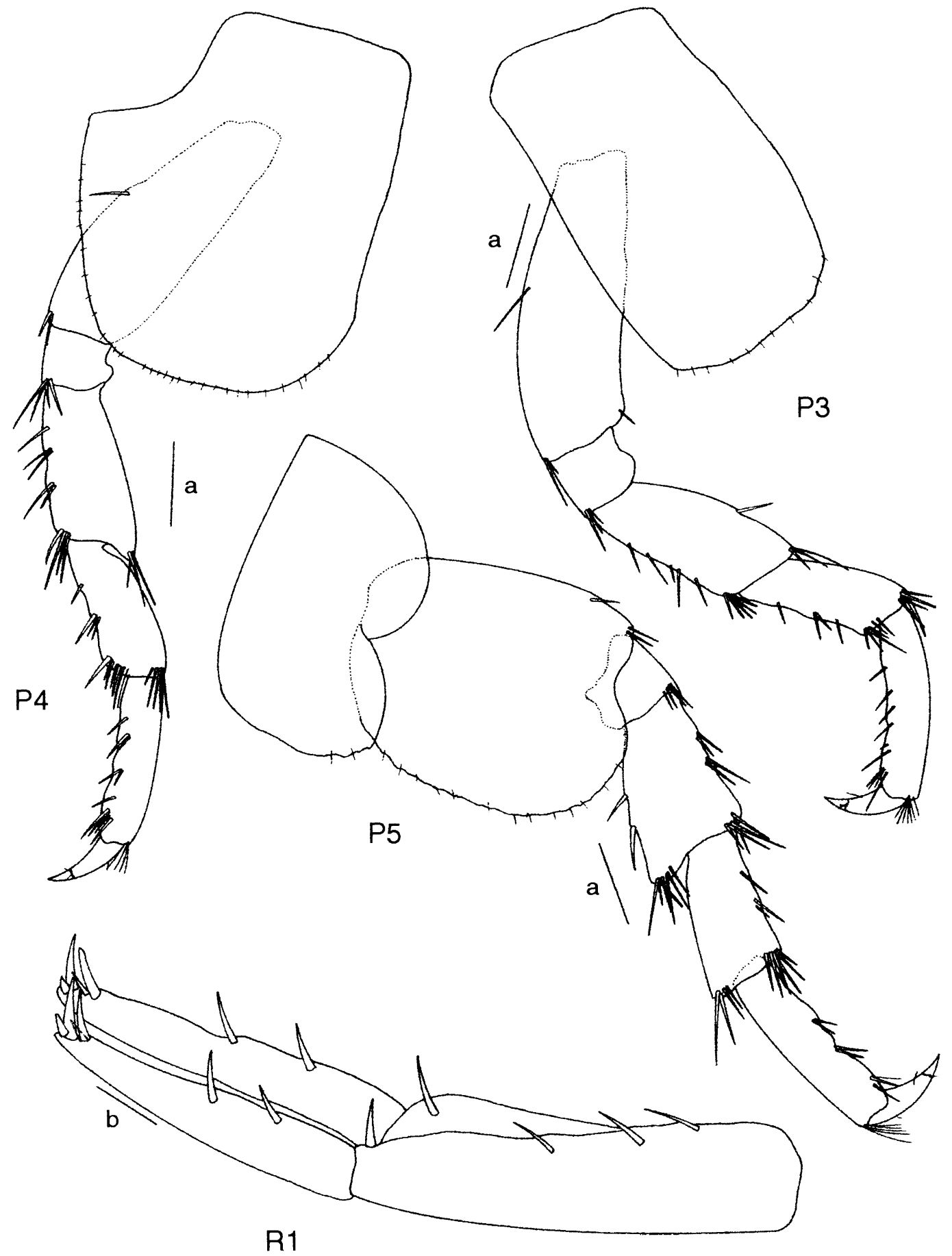

Fig. 3. Hyalella azteca male, length $7.8 \mathrm{~mm}$. Symbols and scale as in Fig. 1 .

longer than rami; rami subequal; inner ramus with 2 dorsal and 5 distal setae, male without curved setae on inner side of the ramus; outer ramus with 2 dorsal and 4 distal setae; peduncle setation present (Fig. 3, R1).
Uropod 2 rami subequal; inner ramus with 2 dorsal and 5 distal setae; outer ramus with 2 dorsal and 4 distal setae; peduncle setation present (Fig. 2, R2).

Uropod 3 longer than urosomite 3 , shorter 


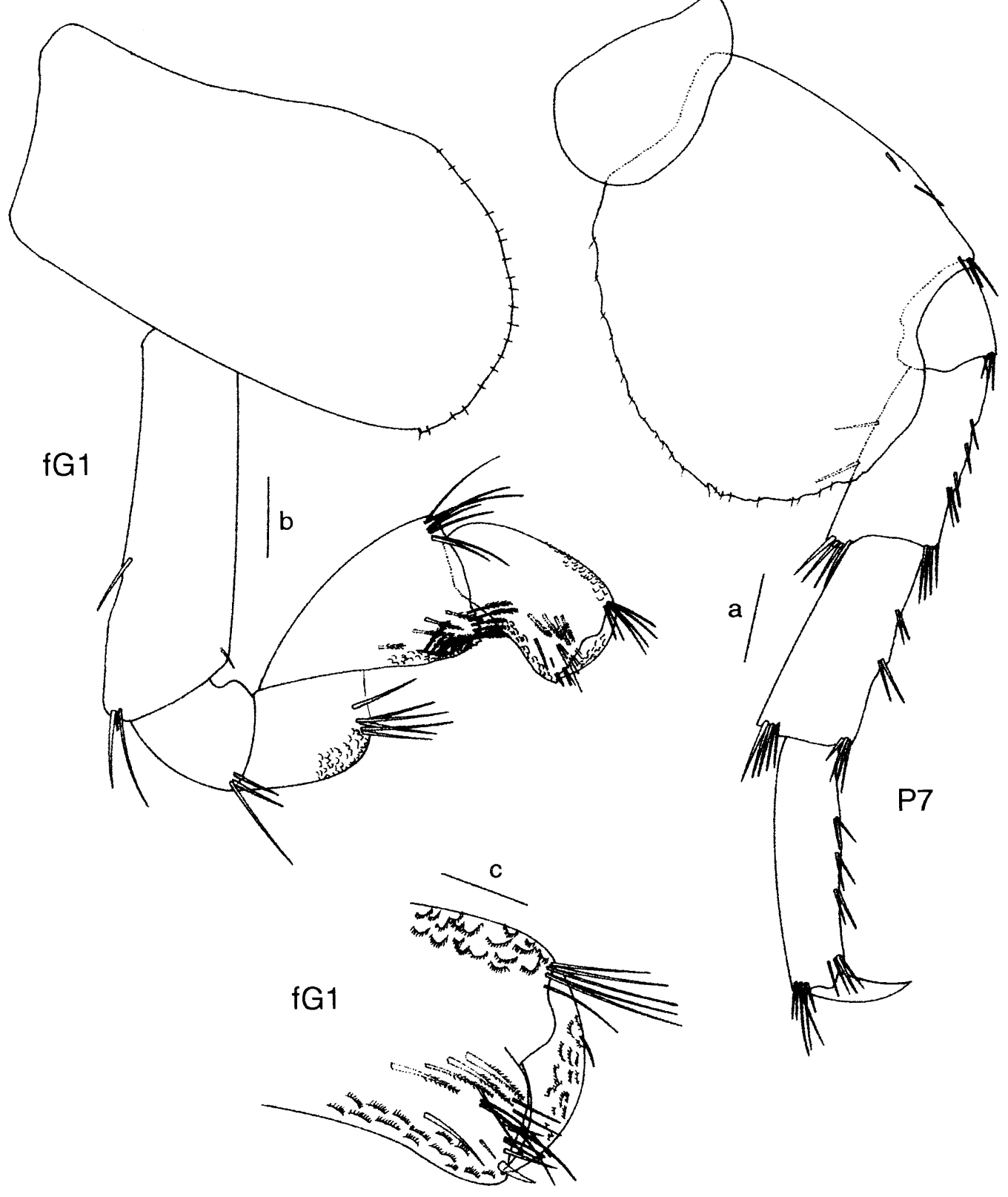

Fig. 4. Hyalella azteca male, length $7.8 \mathrm{~mm}$. Female "f," length $5.6 \mathrm{~mm}$. Symbols and scale as in Fig. 1 .

than peduncle of uropod 1 , but longer than peduncle of uropod 2; peduncle slender, but wider than ramus, with 3 strong distal setae, and 2 marginal setae; without special peduncular processes; inner ramus absent; outer ramus uniarticulate, same length as peduncle, styliform, with 4 simple, and 1 connate apical setae (Fig. 2, R3).

Telson as wide as long, entire, fleshy, smooth; apically pointed, but round, with 2 apposed long simple apical setae (Fig. 2, T). Gills. Coxal gills saclike, on segments 2 to 6. Sternal gills tubular, on segments 3 to 7 .

Characters of Female That Differ from Male.-Size, $5.6 \mathrm{~mm}$. Antenna 1 flagellum with 8 articles. Antenna 2 similar in shape to male, flagellum with 7 articles. Gnathopod 1 like gnathopod 2 in size, and similar in size to male gnathopod 1 (Fig. 4, fG1). Gnatho- 


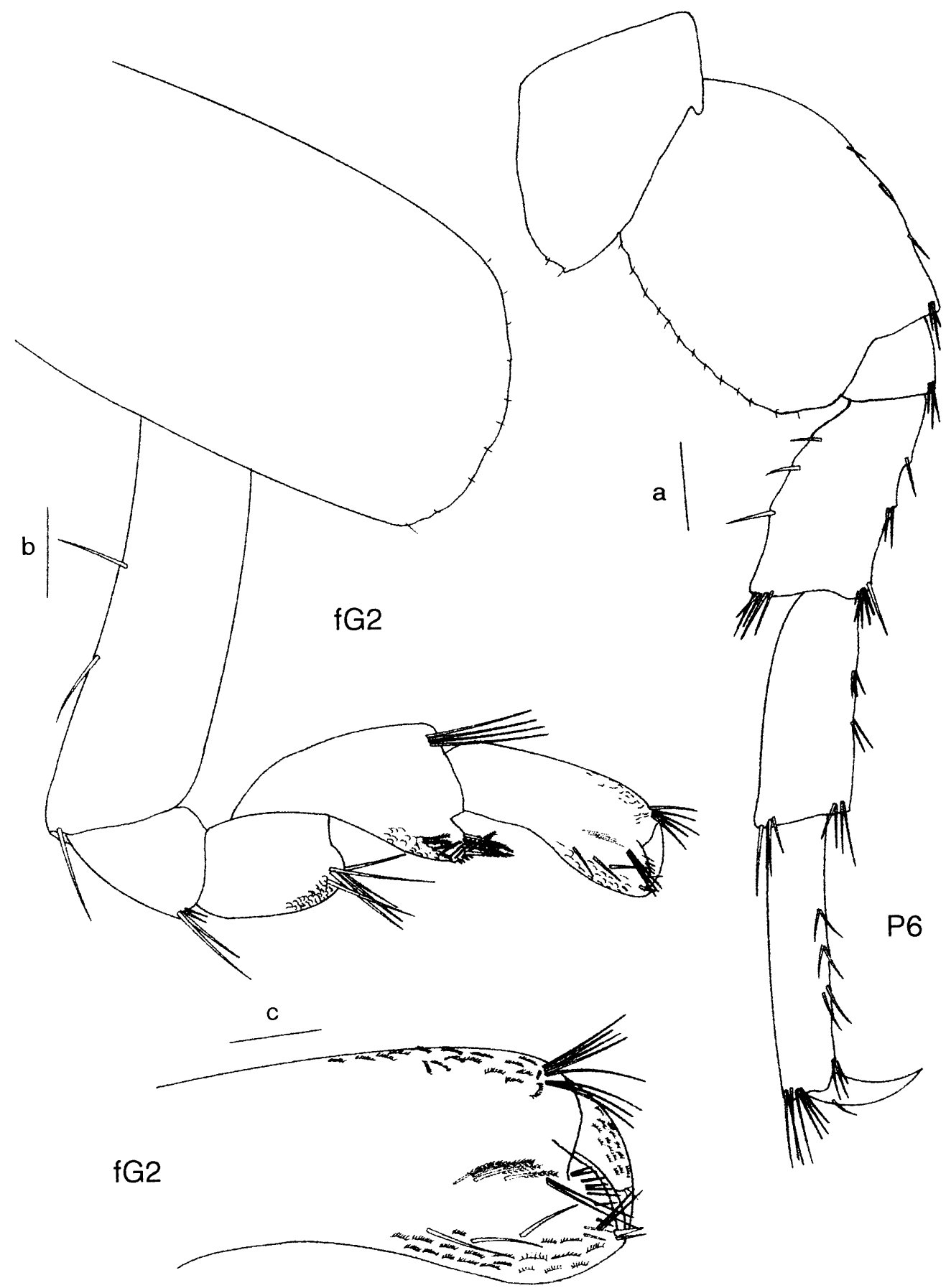

Fig. 5. Hyalella azteca male, length $7.8 \mathrm{~mm}$. Female "f," length $5.6 \mathrm{~mm}$. Symbols and scale as in Fig. 1 .

pod 2 smaller and different in shape from male gnathopod 2, propodus slender, weakly parachelate, palm reverse oblique (Fig. 5, fG2).

Habitat.-Freshwater, epigean, littoral.
Type Material.-Muséum d'Histoire Naturelle, Ville de Genève, Switzerland.

Type Locality.-Vera Cruz, Mexico. Saussure (1858) also collected specimens from a stream at a park in Chapultepec, but he men- 
tioned that the state of conservation is too bad to allow any study. We believe that the specimens examined were from Veracruz. The syntype series is labeled only "Mexique").

\section{DISCUSSION}

As presently understood, the diversity of the genus Hyalella in North America makes it necessary to review in detail the species in all the localities where the complex is present. The need for reviewing the morphology of the several populations identified as Hyalella azteca has already been stressed by Duan et al. (1997). Any further ecological or toxicological studies should confirm the identity of the populations being worked with.

Without doubt, Hyalella azteca should be considered a species complex. The other five related species known from North America are an indication of the diversity present. The genetic evidence (Thomas et al., 1994, 1997, 1998; Duan et al., 1997, 2000; Hogg et al., 1998; Witt and Hebert, 2000) and ecological studies (France, 1992; Wellborn, 1994a, b, 1995, 2000; McPeek and Wellborn, 1998) have shown the degree of heterogeneity of the populations within the distributional range of the species.

From the description given here, we suspect that $H$. faxoni Stebbing, 1903, should be a valid species. Hyalella knickerbockeri (Bate, 1862) needs to be examined because it has priority; unfortunately the exact type locality is not known. Hyalella dentata Smith, 1874 , and $H$. inermis Smith, 1875, are probably valid species, but because the types are unknown (and most likely lost), their availability is doubtful. Hyalella fluvialis (Harford, 1877 ) is poorly described and not figured, and its validity is also doubtful. All other records for $H$. azteca in North America should be reviewed and compared with the description given here.

We have looked at the type material of $H$. ornata Pearse, 1911, and find that this species is a synonym of $H$. azteca. Some slight morphological differences were found, mainly on the medial inner margin of the carpus on gnathopod 1 in male and female. Hyalella ornata has a row of five or six long setae on that article, whereas $H$. azteca has only two short setae. Gnathopod 2 in males are also slightly different. The differences could be attributed to the smaller sizes of the $H$. ornata specimens $(5.0-5.3 \mathrm{~mm})$. Some of the seta- tion differences could be because the samples of $H$. azteca were originally stored as dried specimens and later hydrated in the Museum.

After examining specimens identified as $H$. azteca from Brazil (Pereira, 1983), we are sure that they represent a new species, as do the records of $H$. knickerbockeri from Peru (Weckel, 1910). We also doubt the record from Venezuela (Villarroel and Graziani, 1995). Hyalella azteca as described by Bousfield $(1973,1996)$ does not agree with the description given here, nor do the figures and short descriptions of $H$. azteca given by Stevenson and Peden (1973), Cole and Watkins (1977), or Pennak (1989).

We have had access to samples identified as $H$. azteca from Maine, Texas, Mississippi, Michigan, Oklahoma, and Hawaii in the U.S.A, Chihuahua and Nuevo Leon in Mexico, and several samples from Costa Rica, Dominica, Puerto Rico, Cuba, Panama, and Jamaica. Most of these samples reflect the diversity of the complex and will be described as new species in a series of publications currently in preparation.

Among the morphological characters that we have found more useful in distinguishing the species of the azteca complex are: the relative size of the antennae; the number of setae on the inner plate of maxilla 1; the setae organization on the palp of the maxilliped; the number and organization of setae on the propodus of gnathopod 1; the posterior setation of the basis, the shape of the propodus, and the irregular shape of the palm on gnathopod 2; the shape of the epimeral plates; the structure of uropod 3 , especially the setation and the ratio of peduncle to ramus; and the shape and setation of the telson.

The species complex forms a good clade with several synapomorphies. Among them are the long slender propodus and inverse oblique palm of gnathopod 2 in females, the two strong pappose setae on the inner margin of the inner plate of maxilla 2 , the truncated process on the proximal margin of the gnathopod 2 palm in males, and the three strong setae on the inner plate of maxilla 1 (the presence of two setae is also seen in some morphs). These characters are unique features of the complex. The above features are not seen in any of the specimens we have examined from South America, either west or east of the Andes. The presence of five pairs of sternal gills in the azteca complex and in 
the species west of the Andes could indicate some degree of relationship between these two groups.

\section{ACKNOWLEDGEMENTS}

We thank Dr. Peter Schwendinger from the Muséum d'Histoire Naturelle, Ville de Genève, Switzerland, who loaned us the material for this study. Dr. Brian Kensley and Elizabeth Nelson from Smithsonian Institution loaned material of Hyalella from Central America and Mexico. Dr. James D. Thomas from Nova University let us borrow material from Hawaii. Dr. Sara LeCroy from the Gulf Coast Research Laboratory, University of Southern Mississippi, provided material from Texas, Mississippi, and Cayman Islands. Dr. Gary Wellborn provided some literature, discussions, and encouragement. We also thank two anonymous reviewers for greatly clarifying and improving the manuscript. The first author was supported in part by Universidad Católica del Norte, Chile; University of Maine, U.S.A.; a grant from the Lerner-Gray Fund for Marine Research; and grants from the Association of Graduate Students, University of Maine.

\section{LITERATURE CITED}

Baldinger, A. J., W. D. Shepard, and D. L. Threloff. 2000 Two new species of Hyalella (Crustacea: Amphipoda: Hyalellidae) from Death Valley National Park, California, U.S.A.-Proceedings of the Biological Society of Washington 113: 443-457.

Barnard, J. L., and C. M. Barnard. 1983. Freshwater Amphipoda of the World. I. Evolutionary Patterns. II. Handbook and Bibliography. Hayfield Associates, Virginia. $830 \mathrm{pp}$.

Bate, C. S. 1862. Catalogue of the Specimens of Amphipodous Crustacea in the Collection of the British Museum. British Museum (Natural History), London. $399 \mathrm{pp}$.

Bousfield, E. L. 1958. Freshwater amphipod crustaceans of glaciated North America.- The Canadian Field Naturalist 72: 55-113.

1973. Shallow-water Gammaridean Amphipoda of New England. Cornell University Press, Ithaca, New York. $312 \mathrm{pp}$.

-1996. A contribution to the reclassification of Neotropical freshwater hyalellid amphipods (Crustacea: Gammaridea, Talitroidea).-Bolletino del Museo Civico di Storia Naturale de Verona 20: 175-224.

Cole, G. A., and R. L. Watkins. 1977. Hyalella montezuma, a new species (Crustacea: Amphipoda) from Montezuma Well, Arizona.-Hydrobiologia 52: 175-184.

Dallwitz, M. J., T. A. Paine, and E. J. Zurcher. 1999. User's Guide to the DELTA System. A General System for Processing Taxonomic Descriptions. Edition 4.10. Division of Entomology, CSIRO, Australia. $168 \mathrm{pp}$.

Duan, Y., S. I. Guttman, and J. T. Oris. 1997. Genetic differentiation among laboratory populations of Hyalella azteca: implications for toxicology.-Environmental Toxicology and Chemistry 16: 691-695.

,-- , and $\longrightarrow$. 2000. Genetic structure and relationships among populations of Hyalella azteca and H. montezuma (Crustacea: Amphipoda).- -Journal of the North American Benthological Society 19: 308-320.
Embody, G. C. 1910. A new freshwater amphipod from Virginia, with some notes on its biology.-Proceedings of the United States National Museum 38: 299-305.

$\rightarrow$ France, R. L. 1992. Biogeographical variation in sizespecific fecundity of the amphipod Hyalella azteca.Crustaceana 62: 240-248.

Faxon, W. 1876. Exploration of Lake Titicaca by Alexander Agassiz and S. W. Garman. IV. Crustacea.Bulletin of the Museum of Comparative Zoology 3: 361-375.

González, E. 1991. Actual state of gammaridean Amphipoda taxonomy and catalogue of species from Chile.-Hydrobiologia 223: 47-68.

Harford, W. G. W. 1877. Description of a new genus and new species of sessile eyed Crustacea.-Proceedings of the California Academy of Sciences 7: 53-55.

Hogg, I. D., C, Larose, Y. de Lafontaine, and K. G. Doe. 1998. Genetic evidence for a Hyalella species complex within the Great Lakes-St. Lawrence River drainage basin: implications for ecotoxicology and conservation biology.-Canadian Journal of Zoology 76: 1134-1140.

Lazo-Wasem, E. A., and M. F. Gable. 1989. First report of a freshwater amphipod (Gammaridea: Hyalellidae), Hyalella azteca (Saussure), from nonanchihaline waters of Bermuda.-Postilla 204: 1-4

Mateus, A., and E. Mateus. 1990. Etude d'une collection d'amphipodes specialement du sud-ouest asiatique-du Museum d'Histoire Naturelle de Vienne (Autriche).Annalen des Naturhistorischen Museums in Wien, Serie B Botanik und Zoologie 91: 273-331.

McPeek, M. A., and G. A. Wellborn. 1998. Genetic variation and reproductive isolation among phenotypically divergent amphipod populations.-Limnology and Oceanography 43: 1162-1169.

Media Cybernetics, L. P. 1997. Image-Pro Plus for Windows. Reference Guide. 480 pp.

Oshel, P. E., and D. H. Steele. 1988. Comparative morphology of amphipod setae, and a proposed classification of setal types.-Crustaceana Supplement 13: 100-106.

Pearse, A. S. 1911. Report on the Crustacea collected by the University of Michigan-Walker expedition in the state of Vera Cruz, Mexico.-Michigan Academy of Sciences, Report 13: 108-114.

- 1913. Notes on Crustacea acquired by the $\mathrm{Mu}$ seum.-Occasional Papers of the Museum of Zoology, University of Michigan 1: 1-4.

1914. Report on the Crustacea Collected by the Walker-Newcomb expedition in Northeastern Nevada in 1912.-Occasional Papers of the Museum of Zoology, University of Michigan 3: 1-4.

. 1921. Crustacea from Lake Valencia, Venezuela.-Proceedings of the United States National Museum 59: 459-462.

Pennak, R. W. 1989. Fresh-water Invertebrates of the United States, Protozoa to Mollusca. John Wiley and Sons, New York. 628 pp.

Pereira, V. F. G. C. 1983. Espécies Brasileiras do genero Hyalella (Crustacea-Amphipoda). Dissertação apresentada a Coodenação de Pós-Graduação em Zoologia da Universidade Federal do Rio de Janeiro, para obtenção de Grau de Mestre. Rio de Janeiro, Brazil. $1-93$.

Ruffo, S. 1947. Studi sui crostaci anfipodi. XV. Su alcune speciedi anfipodi dell'Argentina e della Terra del Fuoco.-Bolletino del Laboratorio di Entomologia Agraria di Portici 7: 326-332. 
Saussure, H. 1858. Mémoire sur divers crustacés nouveaux des Antilles et du Mexique.-Mémoires de la Société de physique et d'histoire naturelle de Genève 14: 417-496.

Say, T. 1818. An account of the Crustacea of the United States.-Journal of the Academy of Sciences of Philadelphia 1: 313-401.

Shoemaker, C. R. 1933. Amphipoda from Florida and West Indies.-American Museum Novitates 598: 1-24. 1935. The amphipods of Porto Rico and the Virgin Islands. - New York Academy of Sciences, Scientific Survey of Porto Rico and the Virgin Islands 15: 229-262.

- 1942. Notes on some American fresh-water amphipod crustaceans and descriptions of a new genus and two new species.-Smithsonian Miscellaneous Collection 101: 1-31.

- 1948. The Amphipoda of the Smithsonian Roebling Expedition to Cuba in 1937.-Smithsonian Miscellaneous Collection 110: 1-15.

Smith, S. I. 1874. The Crustacea of the freshwaters of the United States. A Synopsis of the higher freshwater Crustacea of the Northern United States, Appendix F. Natural History.-United States Commissioner of Fish and Fisheries. Report of the Commissioner for 1872 and 1873: 2: 637-661.

- 1875. Report on Amphipod Crustaceans.-Annual Report of the United States Geological and Geographical Survey of the Territories, Embracing Colorado. The Exploration for the year 1873, by F. V. Hayden, Washington, Government Printing Office, 1874: 608-611.

Stebbing, T. R. R. 1903. Amphipoda from Costa Rica.Proceedings of the United States National Museum 21: 925-931.

-1906. Amphipoda I. Gammaridea.-Das Tierreich 21: 1-806.

Stevenson, M. M., and A. E. Peden. 1973. Description and ecology of Hyalella texana n. sp. (Crustacea: Amphipoda) from the Edwards Plateau of Texas.-The American Midland Naturalist 89: 426-436.

Strong, D. R. 1972. Life history variation among populations of an amphipod (Hyalella azteca).-Ecology 53: 1103-1111.

Thomas, E. P. D., W. Blinn, and P. Keim. 1994. A test of an allopatric speciation model for congeneric am- phipods in an isolated aquatic ecosystem.--Journal of the North American Benthological Society 13: 100-109.

— divergence among desert spring amphipod populations.-Freshwater Biology 38: 137-143. , and - 1998. Do xeric landscapes increase genetic divergence in aquatic ecosystems? Freshwater Biology 40: 587-593.

Villarroel, E. J., and C. A. Graziani. 1995. Dispersión de Hyalella azteca (Amphipoda: Hyalellidae) hacia Venezuela.- Revista de Biología Tropical 43: 325.

Watling, L. 1989. A classification system for crustacean setae based on the homology concept. Pp. 15-27 in B. E. Felgenhauer, L. Watling, and A. B. Thistle, eds. Functional Morphology of Feeding and Grooming in Crustacea. Crustacean Issues 6. A. A. Balkema, Rotterdam.

- 1993. Functional morphology of the amphipod mandible.-Journal of Natural History 27: 837-849.

Weckel, A. L. 1907. The freshwater Amphipoda of North America.-Proceedings of the United States National Museum 32: 25-58.

-1910. Freshwater amphipods from Peru.-Proceedings of the United States National Museum 38 623,624 .

Wellborn, G. A. 1994a. The mechanistic basis of body size differences between two Hyalella (Amphipoda) species.-Journal of Freshwater Ecology 9: 159-168.

1994b. Size-biased predation and prey life histories: a comparative study of freshwater amphipod populations.-Ecology 75: 2104-2117.

- 1995. Determinants of reproductive success in freshwater amphipod species that experience different mortality regimes.-Animal Behaviour 50: 353-363.

- 2000. Selection on a sexually dimorphic trait in ecotypes within the Hyalella azteca species complex (Amphipoda: Hyalellidae).-American Midland Naturalist 143: 212-225.

Witt, J. D. S., and P. D. N. Hebert. 2000. Cryptic species diversity and evolution in the amphipod genus Hyalella within central glaciated North America: a molecular phylogenetic approach.-Canadian Journal of Fisheries and Aquatic Sciences 57: 687-698.

RECEIVED: 15 September 2000

ACCEPTED: 20 June 2001. 